\title{
Respiratory Suppression and Swallowing from Introduction of Fluids into the Laryngeal Region of the Lamb
}

\author{
HERBERT S. HARNED ${ }^{15}$ JR., JOHN MYRACLE, AND JOSE FERREIRO \\ Department of Pediatrics, University of North Carolina School of Medicine, Chapel Hill, North Carolina, USA
}

\begin{abstract}
Summary
Introduction of $0.9 \% \mathrm{NaCl}$ or undiluted fetal tracheal fluid into the laryngeal region produced no suppression of breathing in lambs during the perinatal period. As $\mathrm{NaCl}$ or tracheal fluid solutions were increasingly diluted with water, progressively greater respiratory suppression associated with rapid swallowing was observed. Introduction of amniotic fluid was associated with variable suppression of respiration. The swallowing induced by the dilute solutions was as rapid as two swallows per sec. Lambs 3 months of age swallowed when water was introduced into the laryngeal region, but were able to alternate swallows between breaths without suppression of breathing.

\section{Speculation}

The suppression of breathing by presence of certain fluids in the laryngeal region may have important clinical implications. At birth, aspiration of amniotic fluid into the laryngeal area could seriously suppress breathing under certain conditions. In the preterm or newly born infant, introduction of fluids with low osmolality into the laryngeal region might initiate this detrimental reflex more strongly than in older children. Finally, the aggravated response where life-threatening apnea develops from presence of small amounts of fluid in the laryngeal region might occur especially in neonatal disease states predisposing to apneic episodes. Under such conditions, swallowing could clear the liquid from the laryngeal region so that this area would be free of fluid at subsequent postmortem examination. Death from apnea could occur as terminal hypoxia supervenes, leaving little evidence for the pathologist to define the cause of death.
\end{abstract}

Apneic episodes in the premature and newborn occur under a variety of conditions, but frequently occur in relation to feedings (1). Incomplete coordination of deglutition and breathing during the neonatal period may predispose the infant to such apneic episodes, which may be life threatening.

Clinical observations of deglutition by esophageal pressure recordings have revealed incompletely developed patterns of swallowing in the neonatal term and preterm infant (2). These appear to become more effectively coordinated after several days of life. Animal studies have revealed that chemosensitive reflexes initiated by the presence of certain fluids in the laryngeal region suppress breathing (3-5) and that swallowing occurs concurrently with this respiratory suppression $(4,5)$. The swallowing and respiratory suppression result from selective reactions to the presence of various solutions (5). Storey and Johnson (6) have suggested that the sensing units react to water and to flow of fluid and that taste and tactile modalities are less important in initiating these responses. The afferent pathway of this reflex is through the superior laryngeal nerves $(3,5,7)$.

The present studies were performed to evaluate further the association of deglutition and respiratory suppression during these reflexes as revealed in fetal, neonatal, and 3-month-old lambs and to project clinical ramifications which deserve further evaluation.

\section{MATERIALS AND METHODS}

The studies were performed on 38 full term lambs delivered by hysterotomy from spinally anesthetized ewes. Using methods similar to those previously described $(4,8)$, a fetal tracheostomy was performed under local anesthesia and a fluid-filled tube was inserted for intratracheal pressure recording. Also, in lambs where neonatal observations were to be made, a catheter was passed into the right jugular vein and its tip placed in the superior vena cava for recording of intrathoracic pressures.

A polyvinyl motility catheter was introduced into the upper esophagus for recording of intraesophageal pressure fluctuations associated with swallowing. A midline cut with iris scissors in the larynx immediately cephalad to the vocal cords exposed this area for direct introduction of various types of fluids. Swallowing and breathing could both be visualized as well as being recorded simultaneously.

The superior laryngeal nerves were identified readily as they entered the laryngeal area above the vocal cords. This was accomplished with careful attention directed toward avoiding injury to these nerves and to adjacent structures.

The surgical procedures described above were accomplished usually with the lamb in utero except for its head and neck. The lamb was then delivered into an environmental box at the ewe's side and was secured on its back in an ambient air environment.

Breathing of the lamb was induced by sprinkling its fleece with water at $20-25^{\circ}$. This procedure was successful in initiating breathing in all but eight of the lambs. In these animals, partial immersion in water for continued cool stimulation (8) was necessary to insure continuance of rhythmic breathing between experiments. Since their breathing patterns were essentially the same as those of the lambs induced to breathe by sprinkling of the fleece, these animals were included in the specific studies to be described.

Fluids were introduced into the laryngeal region above the vocal cords by a syringe delivering approximately $5 \mathrm{cc}$ in $15 \mathrm{sec}$ in each experiment in the four groups of experiments described below. This volume and rate was selected so that the fluid instilled in the laryngeal region was not cleared by swallowing during this 15-sec interval. The fluids were injected into the larynx at an average of 2.5 -min intervals over a period averaging $41 \mathrm{~min}$. Since rhythmic breathing usually recovered quite rapidly after the instillation of fluid, the intervals between introduction of the fluids exceeded $5 \mathrm{~min}$ in only $4 \%$ of the experiments, but were extended when surgical division of the superior laryngeal nerves and delivery were accomplished.

Several animals showed persistent apnea after instillation of fluid and required additional sprinkling with water to reinitiate breathing. No differences were observed in the effects of fluids instilled at fetal temperature $\left(40^{\circ}\right)$ and at room temperature of approximately $25^{\circ}$, so most fluids were introduced at the latter temperature. The $\mathrm{pH}$ of the solutions was not adjusted. 
The fetal animals showed changes in blood gases from mean pretest values of $\mathrm{PO}_{2} 20.5 \mathrm{~mm} \mathrm{Hg}, \mathrm{PCO}_{2} 40.7 \mathrm{~mm} \mathrm{Hg}, \mathrm{pH} 7.36$ to mean values of $\mathrm{PO}_{2} 18.7 \mathrm{~mm} \mathrm{Hg}, \mathrm{PCO}_{2} 44.3 \mathrm{~mm} \mathrm{Hg}$, and $\mathrm{pH}$ of 7.28 at the end of the series of experiments. Newborn blood gas values revealed variable $\mathrm{PO}_{2}$ values in the $20-40 \mathrm{~mm} \mathrm{Hg}$ range and $\mathrm{PCO}_{2}$ and $\mathrm{pH}$ values indicating respiratory and metabolic acidosis (mean $\mathrm{PCO}_{2}$ of $52 \mathrm{~mm} \mathrm{Hg}$ and $\mathrm{pH}$ of 7.21) at the end of these longer experiments, which included as many as 20 individual instillations.

\section{SPECIFIC EXPERIMENTS}

Group I. Various solutions were introduced under direct vision into the laryngeal region of fetal animals. Respiratory rate and intratracheal pressure (in $\mathrm{mm} \mathrm{Hg}$ negative pressure) were recorded for isotonic saline ( 7 experiments), $0.028 \%$ saline ( 7 experiments), gastric fluid (3 experiments), tracheal fluid (7 experiments), amniotic fluid (17 experiments), and water (10 experiments).

Group II. Undiluted and diluted tracheal fluid, water and $0.9 \%$ $\mathrm{NaCl}(900 \mathrm{mg} / 100 \mathrm{ml})$ were introduced similarly into the laryngeal region of fetal animals and swallowing and breaths recorded. Thirty-one experiments were performed with instillation of undiluted tracheal fluid, 28 with tracheal fluid diluted 1:20, 13 with water, and 25 with $0.9 \% \mathrm{NaCl}$. Sixteen of these animals were studied before and after bilateral division of the superior laryngeal nerves.

Group III. Other lambs were studied after air breathing was permitted by detachment of the fluid-filled tube attached to the tracheal cannula. The umbilical cord was occluded completely in these animals, hereafter designated as "newborn." Respirations were recorded from a catheter in the superior vena cava which noted negative inspiratory pressures; swallowing was recorded in the same manner as in the fetal animals. Thirty experiments were performed with introduction of undiluted tracheal fluid, 31 with tracheal fluid diluted $1: 4$, and 33 with tracheal fluid diluted $1: 20$. Observations were made before and after bilateral division of the superior laryngeal nerves in 13 of these animals also.

Group IV. Four 3-month-old lambs were anesthetized with chloralose-urethane anesthesia and subjected to procedures similar to those of the newborn lambs. Esophageal pressure recordings and superior vena caval cannulations for recording negative inspiratory pressures were performed and the larynx was exposed for introduction of fluids. The effects on swallowing and breathing were tested with solutions of $0.9 \% \mathrm{NaCl}$ (14 experiments), $0.45 \%$ $\mathrm{NaCl}$ (14 experiments), $0.225 \% \mathrm{NaCl}$ (14 experiments), and water (15 experiments).

The Mann-Whitney U-test (9) was applied in statistical analyses of these four groups of experiments involving nonparametric data. Comparisons were made between the baseline observations and those during the $0-5-$ and $5-10$-sec intervals after the various fluids were instilled. This statistical method tests the hypothesis that the two populations have the same distribution (no statistical significance in the differences) or the alternative that one population is stochastically larger than the other (statistical significance in the differences).

\section{OBSERVATIONS OF RATE OF SWALLOWING AND ITS RELATIONSHIP TO BREATHING}

The individual records were studied to delineate patterns and rates of swallowing activity and their effects on respiration under the various conditions described.

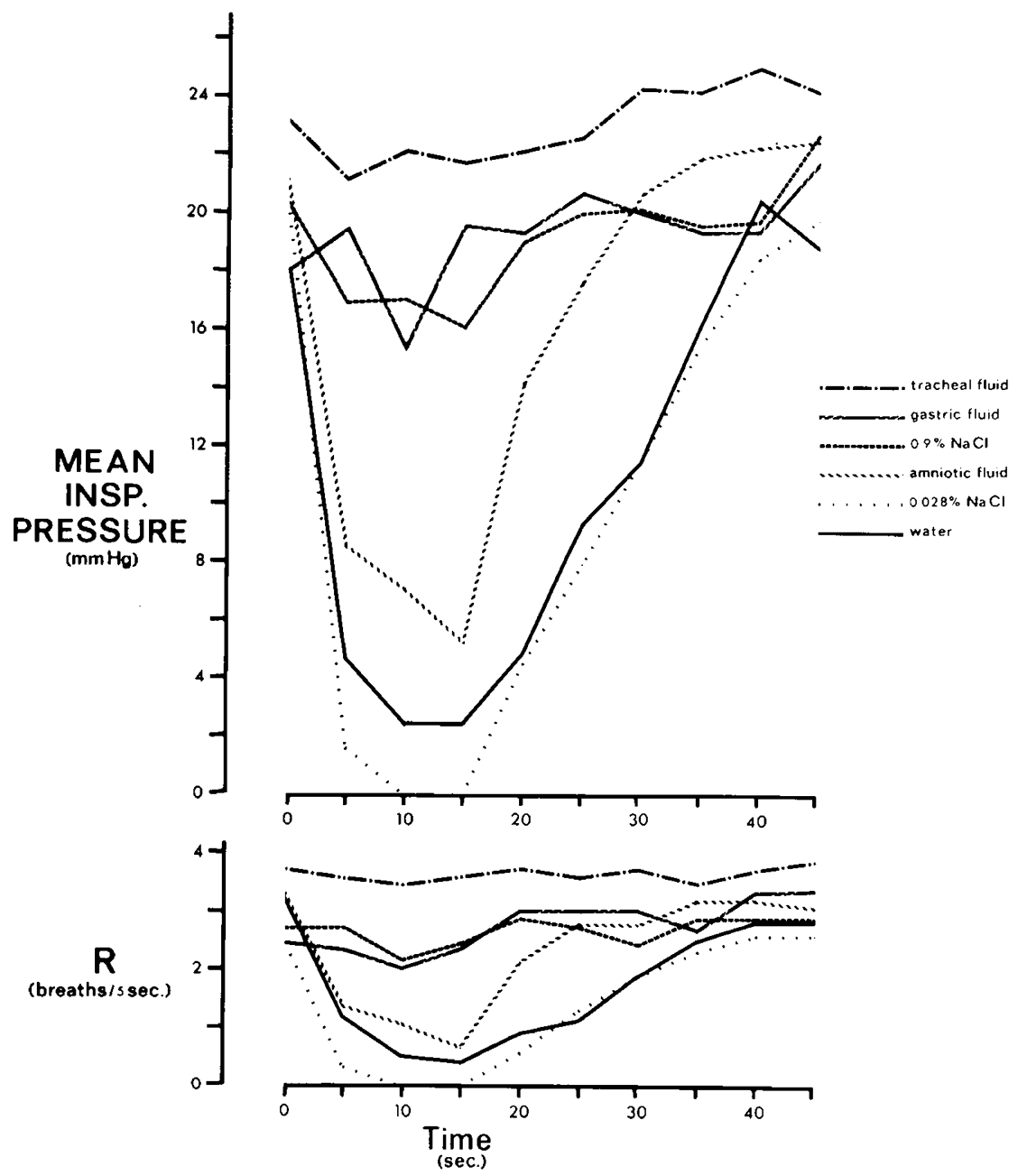

Fig. 1. Effects of laryngeal instillation of various fluids on the inspiratory pressure and rate of breathing of fetal lambs. Mean inspiratory pressure per breath is delineated for each 5 -sec interval. 
Table 1. Mean values and SD for inspiratory pressure (IP) and breaths for basal and 5-sec intervals: Group I, fetal animals (corresponding to Fig. 1$)^{1}$

\begin{tabular}{|c|c|c|c|c|c|c|c|c|c|c|}
\hline & Basal & $0-5$ & $5-10$ & $10-15$ & $15-20$ & $20-25$ & $25-30$ & $30-35$ & $35-40$ & $40-45$ \\
\hline \multicolumn{11}{|l|}{ Water } \\
\hline Mean IP & $\begin{array}{c}18.0 \\
( \pm 4.35)\end{array}$ & $\begin{array}{c}4.63 \\
( \pm 3.88)\end{array}$ & $\begin{array}{c}2.37 \\
( \pm 4.21)\end{array}$ & $\begin{array}{c}2.4 \\
( \pm 4.79)\end{array}$ & $\begin{array}{c}4.80 \\
( \pm 5.61)\end{array}$ & $\begin{array}{c}9.30 \\
( \pm 7.01)\end{array}$ & $\begin{array}{c}11.50 \\
( \pm 7.56)\end{array}$ & $\begin{array}{c}16.20 \\
( \pm 5.12)\end{array}$ & $\begin{array}{c}20.4 \\
( \pm 4.67)\end{array}$ & $\begin{array}{c}18.80 \\
( \pm 4.29)\end{array}$ \\
\hline Breaths $/ 5 \mathrm{sec}$ & $\begin{array}{c}3.18 \\
( \pm 1.14)\end{array}$ & $\begin{array}{c}1.30 \\
( \pm 0.67)\end{array}$ & $\begin{array}{c}0.50 \\
( \pm 0.71)\end{array}$ & $\begin{array}{c}0.40 \\
( \pm 0.70)\end{array}$ & $\begin{array}{c}0.90 \\
( \pm 1.10)\end{array}$ & $\begin{array}{c}1.10 \\
( \pm 0.99)\end{array}$ & $\begin{array}{c}1.90 \\
( \pm 1.20)\end{array}$ & $\begin{array}{c}2.50 \\
( \pm 0.53)\end{array}$ & $\begin{array}{c}2.80 \\
( \pm 0.63)\end{array}$ & $\begin{array}{r}2.80 \\
( \pm 0.79)\end{array}$ \\
\hline \multicolumn{11}{|l|}{$0.028 \% \mathrm{NaCl}$} \\
\hline Mean IP & $\begin{array}{c}19.86 \\
( \pm 4.56)\end{array}$ & $\begin{array}{r}1.57 \\
( \pm 3.74)\end{array}$ & 0 & 0 & $\begin{array}{c}4.43 \\
( \pm 4.39)\end{array}$ & $\begin{array}{c}7.86 \\
( \pm 5.67)\end{array}$ & $\begin{array}{c}11.57 \\
( \pm 8.02)\end{array}$ & $\begin{array}{c}15.43 \\
( \pm 3.55)\end{array}$ & $\begin{array}{c}18.43 \\
( \pm 2.15)\end{array}$ & $\begin{array}{c}19.71 \\
( \pm 3.04)\end{array}$ \\
\hline Breaths $/ 5 \mathrm{sec}$ & $\begin{array}{c}2.45 \\
( \pm 0.21)\end{array}$ & $\begin{array}{c}0.29 \\
( \pm 0.49)\end{array}$ & 0 & 0 & $\begin{array}{c}0.57 \\
( \pm 0.53)\end{array}$ & $\begin{array}{c}1.29 \\
( \pm 0.95)\end{array}$ & $\begin{array}{r}1.86 \\
( \pm 1.35)\end{array}$ & $\begin{array}{c}2.29 \\
( \pm 0.95)\end{array}$ & $\begin{array}{c}2.57 \\
( \pm 0.53)\end{array}$ & $\begin{array}{c}2.57 \\
( \pm 0.53)\end{array}$ \\
\hline \multicolumn{11}{|l|}{ Amniotic fluid } \\
\hline Mean IP & $\begin{array}{c}20.82 \\
( \pm 5.66)\end{array}$ & $\begin{array}{c}8.53 \\
( \pm 7.80)\end{array}$ & $\begin{array}{r}7.06 \\
( \pm 6.42)\end{array}$ & $\begin{array}{c}5.18 \\
( \pm 6.97)\end{array}$ & $\begin{array}{c}14.18 \\
( \pm 5.34)\end{array}$ & $\begin{array}{c}17.65 \\
( \pm 3.72)\end{array}$ & $\begin{array}{c}20.65 \\
( \pm 4.78)\end{array}$ & $\begin{array}{c}21.88 \\
( \pm 4.64)\end{array}$ & $\begin{array}{c}22.24 \\
( \pm 5.79)\end{array}$ & $\begin{array}{c}22.41 \\
( \pm 6.14)\end{array}$ \\
\hline Breaths $/ 5 \mathrm{sec}$ & $\begin{array}{c}3.28 \\
( \pm 0.95)\end{array}$ & $\begin{array}{c}1.35 \\
( \pm 1.27)\end{array}$ & $\begin{array}{c}1.06 \\
( \pm 0.97)\end{array}$ & $\begin{array}{c}0.65 \\
( \pm 0.86)\end{array}$ & $\begin{array}{r}2.12 \\
( \pm 1.11) \\
\end{array}$ & $\begin{array}{c}2.76 \\
( \pm 1.15) \\
\end{array}$ & $\begin{array}{r}2.76 \\
( \pm 0.90) \\
\end{array}$ & $\begin{array}{r}3.18 \\
( \pm 0.88) \\
\end{array}$ & $\begin{array}{r}3.18 \\
( \pm 0.81) \\
\end{array}$ & $\begin{array}{r}3.06 \\
( \pm 0.97) \\
\end{array}$ \\
\hline
\end{tabular}

${ }^{1}$ Values for water, saline, and amniotic fluid illustrate significant changes.

Nineteen additional experiments were performed where the fluids were introduced by single droplets onto the vocal cords. Since this method also induced rapid swallowing and respiratory suppression, these patterns were also evaluated.

\section{RESULTS}

GROUP I

The rate and depth of breathing were recorded in fetal lambs subjected to laryngeal instillation of a variety of solutions as depicted in Figure 1 and Table 1. Note that tracheal fluid, gastric fluid, and $0.9 \% \mathrm{NaCl}$ produced no significant suppression of breathing. When tested for significance for the first $5 \mathrm{sec}$ and for $5-10 \mathrm{sec}$ during instillation of fluid, the number of breaths and strength of breaths both decreased significantly from baseline values in the case of water, dilute $\mathrm{NaCl}$ and amniotic fluid $(P<$ 0.005 in all the experiments). This suppression of breathing for water, dilute $\mathrm{NaCl}$ and amniotic fluid persisted for the 15-sec observation period but usually recovered soon after this (see Table 1). In all the animals tested, swallowing was noted visually at the time of initial respiratory suppression or preceding it.

\section{GROUP II}

The number of swallows and the rate of breathing were observed during the introduction of various dilutions of tracheal fluid, water, and $0.9 \% \mathrm{NaCl}$ as shown in Figure 2 and Table 2. Undiluted tracheal fluid and $0.9 \% \mathrm{NaCl}$ produced minimal swallowing and insignificant suppression of breathing, in marked contrast to the active swallowing and respiratory suppressive effects noted with the introduction of tracheal fluid diluted 1:20 and water. Significant swallowing was elicited, as noted in the $0-5$ and $5-10 \mathrm{sec}$ intervals of instillation of 1:20 tracheal fluid $(P<0.005$ for both intervals) and water $(P<0.005$ for both intervals). Significant suppression of breathing was noted during these test intervals for the 1:20 tracheal fluid $(P<0.005$ for the number of breaths for both the $0-5$ - and 5-10-sec intervals) and for water $(P<0.01$ for the $0-5$-sec interval and $P<0.005$ for the 5-10-sec interval). An intermediate dilution of tracheal fluid (1:4) produced a degree of respiratory suppression between the undiluted and very dilute $(1: 20)$ tracheal fluid. In this group of experiments, the major effects were noted during the 15 -sec period of instillation of fluid and recovery of respiration was noted during the later seconds of observation. The respiratory-suppressive effects of water appeared to be more persistent than those of diluted tracheal fluid (1:20).

During instillation of the dilute fluids, at the time that swallowing was initiated, there was slowing of the heart rate of approximately 20 beats/min, but with recovery to pretest values immediately after instillation was stopped. Carotid arterial flow, measured by a Carolina Medical Electronics electromagnetic flow- meter appeared to rise slightly during the introduction of dilute fluids, but this was not proven to be significant. No changes in heart rate or carotid arterial flow were noted in the experiments where swallowing was not elicited. These fetal lambs were not permitted to exchange air and, since the umbilical circulation was maintained intact, no change in blood gases would be expected during the alterations in breathing (8).

Bilateral division of the superior laryngeal nerves completely abolished swallowing and the associated respiratory suppression in 16 fetal lambs in which the dilute solutions were tested.

\section{GROUP III}

The experiments on newborn lambs are shown in Figure 3 and Table 3 and revealed effects similar to those in the fetal experiments. Undiluted tracheal fluid was associated with no significant decrease in breaths, but some swallowing activity occurred during the $0-5$-sec time interval. Tracheal fluid diluted 1:20 caused significantly decreased breathing $(P<0.005)$ during both time intervals and elicited marked swallowing activity $(P<0.005)$. Tracheal fluid diluted 1:4 with water elicited intermediate responses between these fluids. These newborn lambs were noted to be breathing at approximately 5 breaths $/ 5-\mathrm{sec}$ interval in contrast to the fetal lambs, which were breathing at approximately 3 breaths $/ 5$-sec interval before the solutions were instilled.

The heart rate slowed slightly in these air-breathing animals during swallowing and, when apnea was persistent, the heart rate slowed markedly and carotid blood pressure rose. Carotid arterial blood flow increased slightly during periods when breathing was markedly suppressed.

Bilateral denervation of the superior laryngeal nerves completely abolished both the swallowing activity and respiratory suppression in all 16 newborn lambs in which this was done under all conditions tested.

\section{GROUP IV}

The 3-month-old lambs showed effects differing from those in the previous groups as shown in Figure 4 and Table 4. Swallowing was elicited during introduction of water during the $0-5-\mathrm{sec}$ and $5-10$-sec intervals $(P<0.005$ for both intervals $)$. The other solutions $(0.225 \% \mathrm{NaCl}, 0.45 \% \mathrm{NaCl}$, and $0.9 \% \mathrm{NaCl})$ did not elicit significant swallowing. Despite the active swallowing during water instillation, breathing was not suppressed, nor was breathing altered during introduction of the saline solutions.

\section{RATE OF SWALLOWING ACTIVITY}

In fetal and newborn animals, the suppression of breathing was related quite clearly to the rate of swallowing induced by the various solutions. When very rapid swallowing occurred, apnea developed and at times was sustained. When the swallowing 

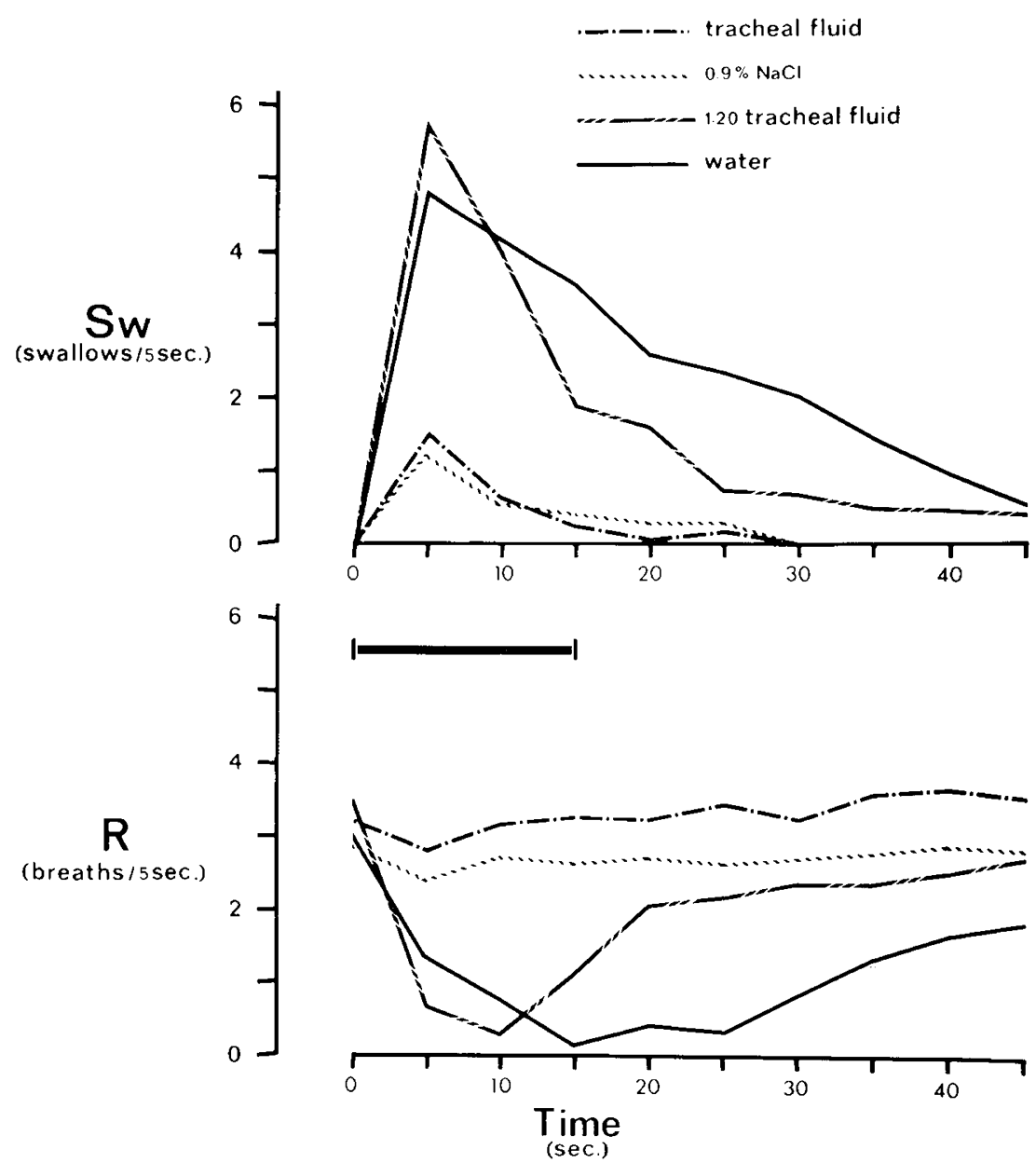

Fig. 2. Effects of laryngeal instillation of various fluids on the number of swallows and rate of breathing of fetal lambs.

Table 2. Mean values and SD for number of swallows and breaths for basal and 5-sec intervals: Group II, fetal animals (corresponding to Fig. 2) ${ }^{1}$

\begin{tabular}{|c|c|c|c|c|c|c|c|c|c|c|}
\hline & Basal & $0-5 \mathrm{sec}$ & $5-10 \mathrm{sec}$ & $10-15 \mathrm{sec}$ & $15-20 \mathrm{sec}$ & $20-25 \mathrm{sec}$ & $25-30 \mathrm{sec}$ & $30-35 \mathrm{sec}$ & $35-40 \mathrm{sec}$ & $40-45 \mathrm{sec}$ \\
\hline \multicolumn{11}{|l|}{ Tracheal fluid } \\
\hline Swallows $/ 5 \mathrm{sec}$ & 0 & $\begin{array}{c}1.48 \\
( \pm 0.89)\end{array}$ & $\begin{array}{c}0.61 \\
( \pm 0.76)\end{array}$ & $\begin{array}{c}0.23 \\
( \pm 0.50)\end{array}$ & $\begin{array}{c}0.03 \\
( \pm 0.18)\end{array}$ & $\begin{array}{c}0.16 \\
( \pm 0.52)\end{array}$ & 0 & 0 & 0 & 0 \\
\hline Breaths $/ 5 \mathrm{sec}$ & $\begin{array}{c}3.21 \\
( \pm 0.74)\end{array}$ & $\begin{array}{c}2.81 \\
( \pm 1.25)\end{array}$ & $\begin{array}{c}3.16 \\
( \pm 1.07)\end{array}$ & $\begin{array}{c}3.26 \\
( \pm 0.96)\end{array}$ & $\begin{array}{c}3.22 \\
( \pm 0.94)\end{array}$ & $\begin{array}{r}3.45 \\
( \pm 1.15)\end{array}$ & $\begin{array}{c}3.23 \\
( \pm 0.88)\end{array}$ & $\begin{array}{r}3.58 \\
( \pm 0.89)\end{array}$ & $\begin{array}{c}3.65 \\
( \pm 0.95)\end{array}$ & $\begin{array}{r}3.55 \\
( \pm 1.03)\end{array}$ \\
\hline \multicolumn{11}{|l|}{$0.9 \% \mathrm{NaCl}$} \\
\hline Swallows $/ 5 \mathrm{sec}$ & 0 & $\begin{array}{c}1.16 \\
( \pm 0.69)\end{array}$ & $\begin{array}{c}0.48 \\
( \pm 0.77)\end{array}$ & $\begin{array}{c}0.36 \\
( \pm 0.76)\end{array}$ & $\begin{array}{c}0.23 \\
( \pm 0.51)\end{array}$ & $\begin{array}{r}0.25 \\
( \pm 0.85)\end{array}$ & 0 & 0 & 0 & 0 \\
\hline $\begin{array}{c}\text { Breaths } / 5 \mathrm{sec} \\
\text { 1:20 Tracheal fluid }\end{array}$ & $\begin{array}{c}2.82 \\
( \pm 0.97)\end{array}$ & $\begin{array}{c}2.36 \\
( \pm 0.76)\end{array}$ & $\begin{array}{r}2.68 \\
( \pm 0.80)\end{array}$ & $\begin{array}{r}2.60 \\
( \pm 0.65)\end{array}$ & $\begin{array}{r}2.73 \\
( \pm 0.72)\end{array}$ & $\begin{array}{c}2.63 \\
( \pm 0.58)\end{array}$ & $\begin{array}{c}2.71 \\
( \pm 0.62)\end{array}$ & $\begin{array}{r}2.79 \\
( \pm 0.66)\end{array}$ & $\begin{array}{r}2.88 \\
( \pm 0.68)\end{array}$ & $\begin{array}{c}2.83 \\
( \pm 0.56)\end{array}$ \\
\hline \multicolumn{8}{|l|}{ 1:20 Tracheal fluid } & & & \\
\hline Swallows $/ 5 \mathrm{sec}$ & & $( \pm 2.36)$ & $( \pm 1.60)$ & $( \pm 1.21)$ & $( \pm 1.23)$ & $( \pm 0.90)$ & $\begin{array}{c}0.68 \\
( \pm 0.67)\end{array}$ & $\begin{array}{c}0.46 \\
( \pm 0.69)\end{array}$ & $\begin{array}{c}0.43 \\
( \pm 0.63)\end{array}$ & $\begin{array}{c}0.39 \\
( \pm 0.57)\end{array}$ \\
\hline Breaths $/ 5 \mathrm{sec}$ & $\begin{array}{r}3.46 \\
( \pm 0.69)\end{array}$ & $\begin{array}{r}0.64 \\
( \pm 0.87)\end{array}$ & $\begin{array}{c}0.29 \\
( \pm 0.71)\end{array}$ & $\begin{array}{c}1.11 \\
( \pm 1.08)\end{array}$ & $\begin{array}{r}2.07 \\
( \pm 1.74)\end{array}$ & $\begin{array}{r}2.18 \\
( \pm 1.61)\end{array}$ & $\begin{array}{r}2.36 \\
( \pm 1.50)\end{array}$ & $\begin{array}{r}2.36 \\
( \pm 1.57)\end{array}$ & $\begin{array}{c}2.50 \\
( \pm 1.58)\end{array}$ & $\begin{array}{c}2.71 \\
( \pm 1.38)\end{array}$ \\
\hline Swallows $/ 5 \mathrm{sec}$ & 0 & $\begin{array}{r}4.69 \\
( \pm 1.65)\end{array}$ & $\begin{array}{c}4.15 \\
( \pm 1.34)\end{array}$ & $\begin{array}{c}3.54 \\
( \pm 1.27)\end{array}$ & $\begin{array}{c}2.58 \\
( \pm 1.16)\end{array}$ & $\begin{array}{c}2.33 \\
( \pm 0.98)\end{array}$ & $\begin{array}{r}2.00 \\
( \pm 0.95)\end{array}$ & $\begin{array}{c}1.42 \\
( \pm 0.67)\end{array}$ & $\begin{array}{c}0.92 \\
( \pm 0.79)\end{array}$ & $\begin{array}{r}0.50 \\
( \pm 0.52)\end{array}$ \\
\hline Breaths $/ 5 \mathrm{sec}$ & $\begin{array}{c}3.0 \\
( \pm 0.50)\end{array}$ & $\begin{array}{r}1.46 \\
( \pm 1.05) \\
\end{array}$ & $\begin{array}{c}0.77 \\
( \pm 0.83)\end{array}$ & $\begin{array}{c}0.15 \\
( \pm 0.38) \\
\end{array}$ & $\begin{array}{c}0.42 \\
( \pm 0.67)\end{array}$ & $\begin{array}{r}0.33 \\
( \pm 0.49)\end{array}$ & $\begin{array}{c}0.83 \\
( \pm 0.83)\end{array}$ & $\begin{array}{c}1.33 \\
( \pm 1.15)\end{array}$ & $\begin{array}{r}1.67 \\
( \pm 0.98) \\
\end{array}$ & $\begin{array}{c}1.83 \\
( \pm 0.72) \\
\end{array}$ \\
\hline
\end{tabular}

${ }^{1}$ Fluid instillation, $0-15 \mathrm{sec}$; recovery $15-45 \mathrm{sec}$.

slowed, the animal often was capable of coordinating the swallowing and respiratory efforts so as to insure that these did not occur simultaneously, but the strength of breathing was reduced often if swallowing persisted.

In all the experiments where breathing was suppressed, swallowing was observed visually and documented by a rise in the esophageal pressure. The respiratory suppression persisted after the initial swallowing activity ceased, but intermittent swallows occurred as instillation of fluid continued. After instillation of fluid ceased, swallowing cleared the fluid and usually permitted spontaneous resumption of breathing.

The newborn lambs retained this tendency to develop very rapid swallowing associated with respiratory arrest. Figure 5 reveals respiratory suppression associated with rapid swallowing in 


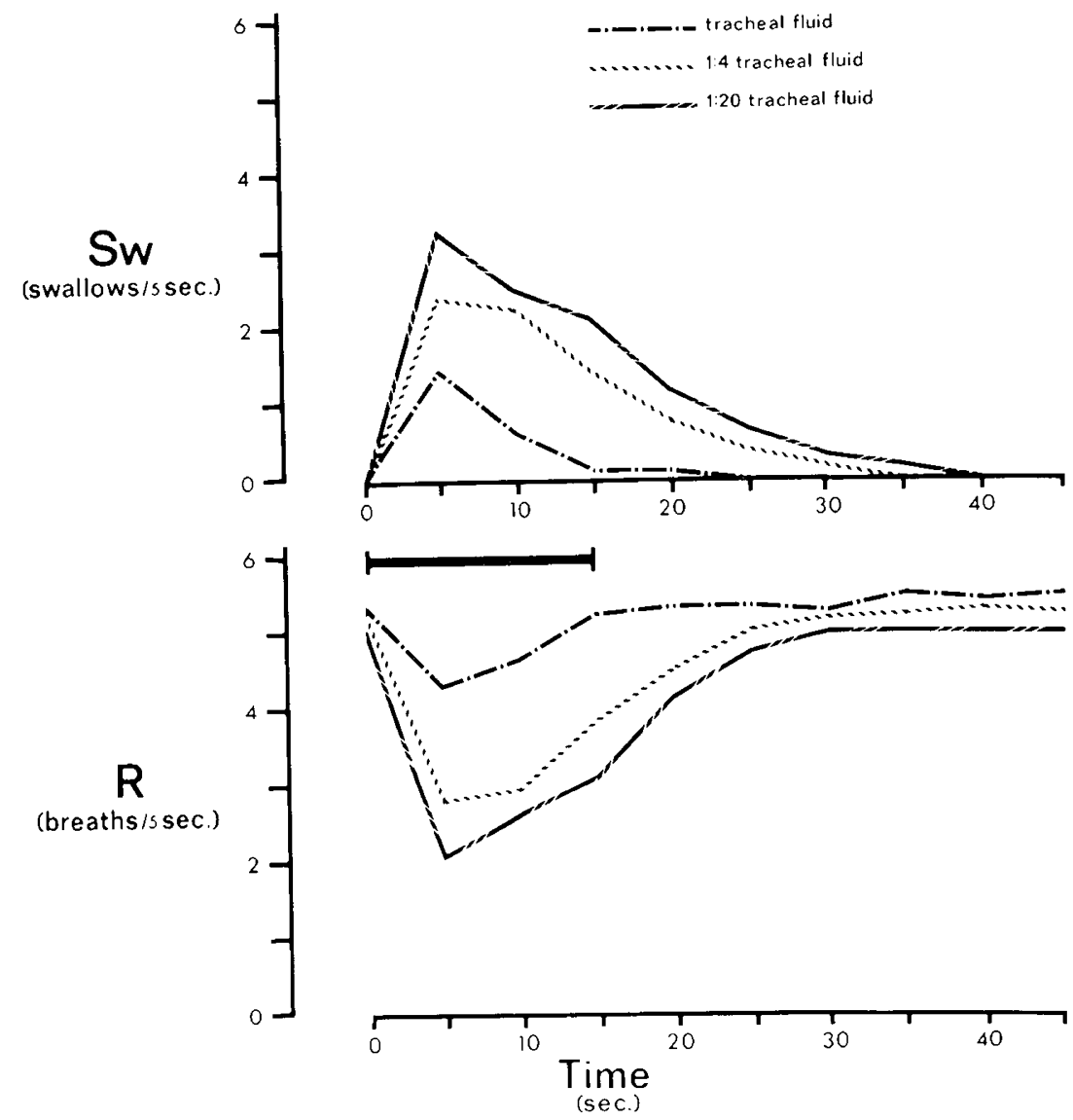

Fig. 3. Effects of laryngeal instillation of various dilutions of tracheal fluid on the number of swallows and breaths in newborn lambs.

Table 3. Mean values and SD for number of swallows and breaths for basal and 5-sec intervals: Group III, newborn animals (corresponding to Fig. 3$)^{1}$

\begin{tabular}{|c|c|c|c|c|c|c|c|c|c|c|}
\hline & Basal & $0-5$ & $5-10$ & $10-15$ & $15-20$ & $20-25$ & $25-30$ & $30-35$ & $35-40$ & $40-45$ \\
\hline \multicolumn{11}{|l|}{ Tracheal fluid } \\
\hline Swallows $/ 5 \mathrm{sec}$ & $\begin{array}{c}0.06 \\
( \pm 0.25)\end{array}$ & $\begin{array}{c}1.45 \\
( \pm 0.93)\end{array}$ & $\begin{array}{c}0.58 \\
( \pm 0.77)\end{array}$ & $\begin{array}{c}0.10 \\
( \pm 0.30)\end{array}$ & $\begin{array}{c}0.10 \\
( \pm 0.40)\end{array}$ & 0 & 0 & 0 & 0 & 0 \\
\hline Breaths $/ 5 \mathrm{sec}$ & $\begin{array}{c}5.28 \\
( \pm 1.79)\end{array}$ & $\begin{array}{r}4.26 \\
( \pm 1.86)\end{array}$ & $\begin{array}{c}4.61 \\
( \pm 1.50)\end{array}$ & $\begin{array}{c}5.29 \\
( \pm 1.74)\end{array}$ & $\begin{array}{c}5.32 \\
( \pm 1.72)\end{array}$ & $\begin{array}{c}5.32 \\
( \pm 1.78)\end{array}$ & $\begin{array}{c}5.26 \\
( \pm 1.77)\end{array}$ & $\begin{array}{c}5.48 \\
( \pm 1.65)\end{array}$ & $\begin{array}{c}5.39 \\
( \pm 1.76)\end{array}$ & $\begin{array}{r}5.45 \\
( \pm 1.65)\end{array}$ \\
\hline \multicolumn{11}{|l|}{ 1:20 Tracheal Fluid } \\
\hline Swallows $/ 5 \mathrm{sec}$ & $\begin{array}{c}0.04 \\
( \pm 0.06)\end{array}$ & $\begin{array}{c}4.11 \\
( \pm 1.90)\end{array}$ & $\begin{array}{c}3.67 \\
( \pm 1.32)\end{array}$ & $\begin{array}{c}3.0 \\
( \pm 1.22)\end{array}$ & $\begin{array}{c}1.18 \\
( \pm 0.88)\end{array}$ & $\begin{array}{c}0.64 \\
( \pm 0.74)\end{array}$ & $\begin{array}{c}0.27 \\
( \pm 0.45)\end{array}$ & $\begin{array}{c}0.15 \\
( \pm 0.51)\end{array}$ & 0 & 0 \\
\hline Breaths $/ 5 \mathrm{sec}$ & $\begin{array}{c}5.94 \\
( \pm 1.33)\end{array}$ & $\begin{array}{r}2.56 \\
( \pm 1.01)\end{array}$ & $\begin{array}{r}3.0 \\
( \pm 1.0) \\
\end{array}$ & $\begin{array}{r}3.67 \\
( \pm 1.80) \\
\end{array}$ & $\begin{array}{r}4.15 \\
( \pm 1.46) \\
\end{array}$ & $\begin{array}{r}4.73 \\
( \pm 1.33) \\
\end{array}$ & $\begin{array}{r}4.97 \\
( \pm 1.57) \\
\end{array}$ & $\begin{array}{r}4.94 \\
( \pm 1.39) \\
\end{array}$ & $\begin{array}{r}4.91 \\
( \pm 1.33)\end{array}$ & $\begin{array}{r}4.85 \\
( \pm 1.37) \\
\end{array}$ \\
\hline
\end{tabular}

${ }^{1}$ Fluid instillation, $0-15 \mathrm{sec}$; recovery $15-45 \mathrm{sec}$.

a newborn lamb. Introduction of tracheal fluid diluted 1:20 elicited a longer than usual period of apnea of approximately $1 \mathrm{~min}$ in this experiment.

The 3-month-old lambs did not show this trait and were able to coordinate swallowing and respiratory activity consistently without interfering with the latter.

Instillation of droplets of dilute fluids always induced swallowing when these were introduced above the vocal cords, but did not induce swallowing when introduced below the cords. Each droplet diffused over a broad surface, which prevented accurate assessment of the regions capable of initiating this reflex. Usually swallowing was associated with early suppression of respiration, but with rapid recovery. On the other hand, prolonged suppression of respiration was observed in two fetal lambs after instillation of a single water droplet and with instillation of a single drop of tracheal fluid diluted 1:20 with water. This was initiated after a short burst of rapid swallowing, but apnea persisted after the swallowing had ceased.

\section{DISCUSSION}

The fetal and newborn lambs responded to fluids with low osmolality with very rapid swallowing efforts, occurring as frequently as two per sec. This rate of swallowing is similar in rapidity to that occurring spontaneously in the fetal sheep, as recorded by chronically implanted electromagnetic flowmeters $(10,11)$ and indicates persistence of such patterns of fetal swallowing to the end of gestation. In contrast, the more mature 3-monthold lambs did not develop such rapid swallows and had no difficulty alternating breathing and swallowing efforts.

All the solutions tested showed very consistent effects with the exception of amniotic fluid. At times when amniotic fluid was introduced, active swallowing and respiratory suppression occurred; at other times very minimal effects were shown; overall the effects illustrated in Figure 1 were influenced by the marked swallowing and depression of breathing observed in some animals. Except for this observation, the effects noted consistently suggested 


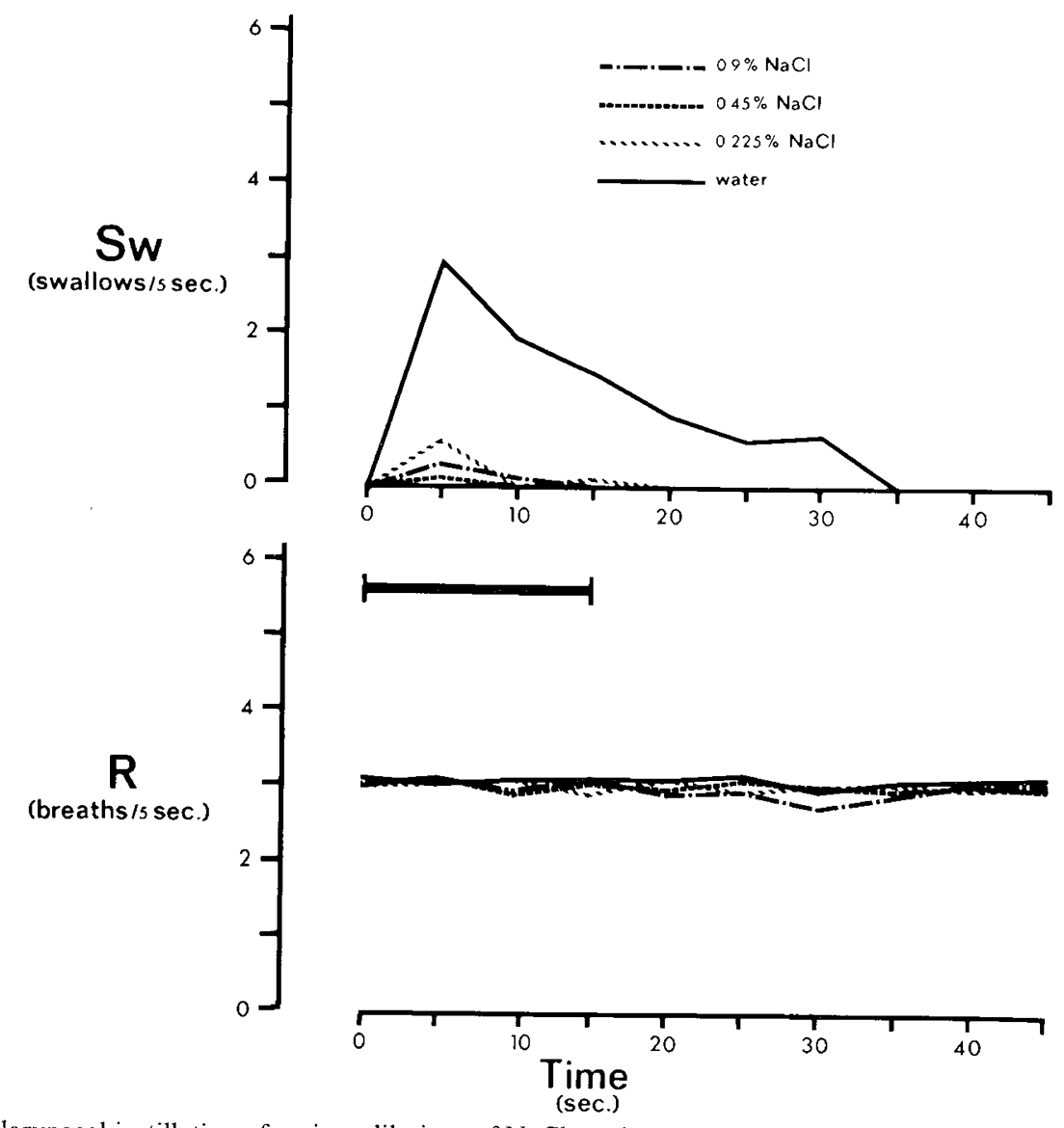

Fig. 4. Effects of laryngeal instillation of various dilutions of $\mathrm{NaCl}$ on the number of swallows and breaths in 3-month-old lambs.

Table 4. Mean values and SD for number of swallows and breaths for basal and 5-sec intervals: Group IV, 3-month-old lambs

\begin{tabular}{|c|c|c|c|c|c|c|c|c|c|c|}
\hline & Basal & $0-5 \mathrm{sec}$ & $5-10 \mathrm{sec}$ & $10-15 \mathrm{sec}$ & $15-20 \mathrm{sec}$ & $20-25 \mathrm{sec}$ & $25-30 \mathrm{sec}$ & $30-35 \mathrm{sec}$ & $35-40 \mathrm{sec}$ & $40-45 \mathrm{sec}$ \\
\hline Swallows $/ 5 \mathrm{sec}$ & 0 & $\begin{array}{c}2.81 \\
( \pm 0.91)\end{array}$ & $\begin{array}{r}1.93 \\
( \pm 1.39)\end{array}$ & $\begin{array}{c}1.47 \\
( \pm 1.25)\end{array}$ & $\begin{array}{r}0.93 \\
( \pm 0.89)\end{array}$ & $\begin{array}{c}0.60 \\
( \pm 0.75)\end{array}$ & $\begin{array}{c}0.67 \\
( \pm 0.87)\end{array}$ & 0 & 0 & 0 \\
\hline Breaths $/ 5 \mathrm{sec}$ & $\begin{array}{r}3.08 \\
( \pm 1.09) \\
\end{array}$ & $\begin{array}{r}2.94 \\
( \pm 1.18) \\
\end{array}$ & $\begin{array}{r}3.07 \\
( \pm 1.10) \\
\end{array}$ & $\begin{array}{r}3.07 \\
( \pm 1.16) \\
\end{array}$ & $\begin{array}{c}3.07 \\
( \pm 1.21)\end{array}$ & $\begin{array}{r}3.13 \\
( \pm 1.07) \\
\end{array}$ & $\begin{array}{r}2.93 \\
( \pm 1.12)\end{array}$ & $\begin{array}{r}3.05 \\
( \pm 1.01) \\
\end{array}$ & $\begin{array}{c}3.10 \\
( \pm 1.05)\end{array}$ & $\begin{array}{r}3.12 \\
( \pm 1.11)\end{array}$ \\
\hline
\end{tabular}
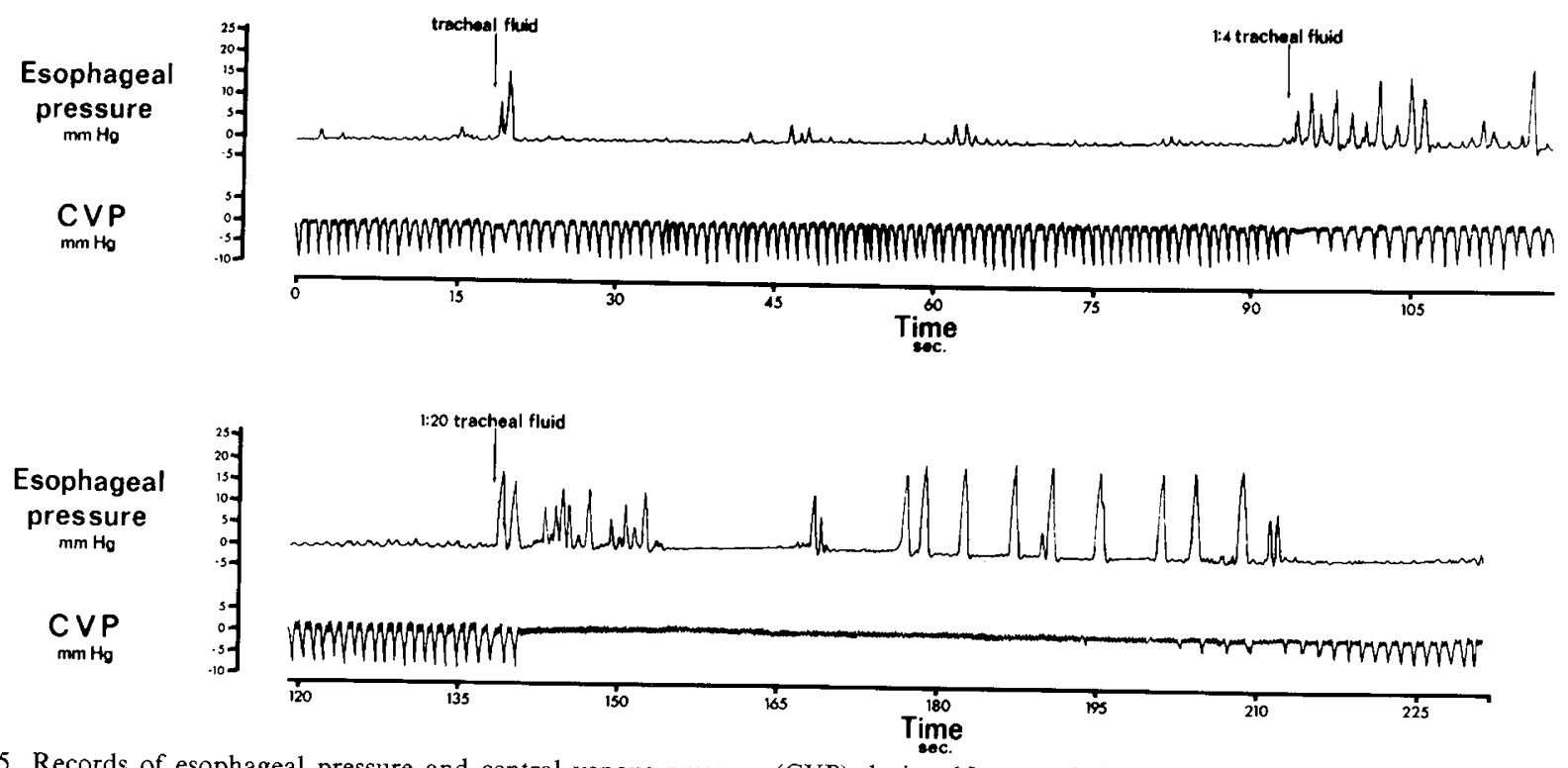

Fig. 5. Records of esophageal pressure and central venous pressure (CVP) during $15-\mathrm{sec}$ periods of instillation of undiluted tracheal fluid and tracheal fluid diluted with water (1:4 and 1:20) in a newborn lamb. Note that suppression of breathing is most marked during instillation of the 1:20 tracheal fluid, is associated initially with rapid swallowing, and persists in this experiment for $45 \mathrm{sec}$. Recording of esophageal pressure changes lagged
about $2 \mathrm{sec}$ after initiation of swallowing. 
that the sensor units in the laryngeal region are "water units" as proposed by Storey and Johnson (6). Differences in the composition of various amniotic fluids tested might account for the erratic responses noted in these experiments where our observation of active swallowing and respiratory suppression is at variance with Johnson's observations (5). Marked variations in osmolality of the amniotic fluid used for the instillations or differences in the taste of the fluid (as suggested by Bradley and Mistretta $(10,12)$ as a reason for variations in fetal swallowing) might be important and will be evaluated in our future experiments.

Attempts were made throughout experiments to introduce each of the fluids in a consistent manner so that differences between the effects of the solutions could not be explained by mechanical factors. In addition, a few attempts were made to mechanically initiate breathing by touching various regions of the larynx with a probe. Swallows occasionally could be elicited, but often vigorous stimulation was applied without inducing swallowing or changes in respiratory patterns. In older animals, Sinclair (13) has elicited sporadic swallowing after stimulation of the pharyngeal mucosa near the vocal cords, but not from the vocal cords themselves. He elicited more consistent swallowing by mechanical stimulation of the posterior pillars and pharyngeal walls. In our experiments, fluids were introduced into the trachea immediately below the larynx without initiating the reflexes described in these studies, indicating that the chemosensitive region was above the larynx.

Several fetal and newborn animals showed a marked degree of respiratory depression, even prolonged apnea, when a single drop of fluid with low osmolality was placed in the region of the vocal cords. This was not the usual pattern and this exaggerated response remains unexplained.

The suppression of breathing in the newborn animals would be expected to cause decreases in $\mathrm{PO}_{2}$ and increases in $\mathrm{PCO}_{2}$ during the laryngeal instillations of dilute fluids, which should bring into play greater peripheral and central respiratory drives. Despite this, the effects of the instillations in the newborn animals were remarkably similar to those in the "fetal" state. We interpreted this as another indication of the strength of these laryngeal chemosensitivity reflexes. The blood gas values of the newborn lambs were not monitored during individual experiments, but serial samplings as the experiments continued showed gradual development of respiratory and metabolic acidosis. No differences were detected in the animals' responses to the instilled fluids as the lambs were studied serially early and late after birth.

These experiments have several important clinical ramifications. First, they indicate that aspiration of amniotic fluid into the laryngeal region immediately before or during birth could seriously suppress the initiation of breathing. The need for rapid suctioning during neonatal resuscitation of even small quantities of fluid from this region is emphasized.

Secondly, in view of the relationship of the respiratory suppressive effects of fluids in the laryngeal region to maturity of the animal, the threat to life from this reflex would be expected to be especially great in the neonatal period and in the premature. Our studies indicate the failure of the lamb during the perinatal period to coordinate rapid swallowing with respiration. However, at 3 months of age, deglutition and swallowing appeared to be well coordinated. This is not surprising since the lamb at 3 months is more mature neurologically than many animals. From studies of the relatively less mature piglet, Downing (7) has emphasized the possible role of laryngeal chemoreflexes in sudden infant death syndrome. Our studies did not reveal that the 3 months' old lamb would be threatened particularly by these reflexes, but such animals may be comparable in maturity to infants older than those most threatened by crib death. Our studies emphasize the association of swallowing with these reflexes and indicate that their further evaluation as a possible mechanism for sudden infant death syndrome should be pursued. Finally, the persistent apnea caused by introduction of a single drop of water into the laryngeal region of some of these lambs was at times very striking and indicates the potential overriding strength of the reflex.

\section{REFERENCES AND NOTES}

1. Brady, J. P., and Brooks, J. G.: The control of breathing. In: A. M. Rudolph: Pediatrics, 16th Ed., p. 1515. (Appleton-Century-Crofts, New York, 1977).

2. Gryboski, J. D.: The swallowing mechanism of the neonate. 1. Esophageal and gastric motility. Pediatrics, 35: 445 (1965).

3. Tchobroutsky, C., Merlet, C., and Rey, P.: The diving reflex in rabbit, sheep and newborn lamb and its afferent pathways. Resp. Physiol., 8: 108 (1969).

4. Harned, H. S., Herrington, R. T., and Ferreiro, J. I.: The effects of immersion and temperature on respiration in newborn lambs. Pediatrics, 45: 598 (1970).

5. Johnson, P., Robinson, J. S., and Salisbury, D.: The onset and control of breathing after birth. In: Foetal and Neonatal Physiology. Proceedings of the Sir Joseph Barcroft Centenary Symposium, pp. 217-221 (Cambridge University Press, Cambridge, 1973)

6. Storey, A. T., and Johnson, P.: Laryngeal water receptors initiating apnea in the lamb. Exp. Neurol., 47: 42 (1975).

7. Downing, S. E., and Lee, J. C.: Laryngeal chemosensitivity: A possible mechanism for sudden infant death. Pediatrics, 55: 640 (1975)

8. Harned, H. S., and Ferreiro, J. I.: Initiation of breathing by cold stimulation: Effects of change in ambient temperature on respiratory activity of the full term fetal lamb. J. Pediat., 83: 663 (1973).

9. Mendenhall, W.: Introduction to Probability and Statistics, 4th Ed., pp. 371-377 (Duxbury Press, North Scituate, MA 1975).

10. Bradley, R. M., and Mistretta, C. M.: The gustatory sense in foetal sheep during the last third of gestation. J. Physiol., 231: 271 (1973).

11. Bradley, R. M., and Mistretta, C. M.: The sense of taste and swallowing in foetal sheep. In: Foetal and Neonatal Physiology, Proceedings of the Sir Joseph Barcroft Centenary Symposium, pp. 77-81 (Cambridge University Press, Cambridge, 1973).

12. Bradley, R. M., and Mistretta, C. M.: Swallowing in fetal sheep. Science, 179: 1016 (1973).

13. Sinclair, W. J.: Initiation of reflex swallowing from the naso and oropharynx. Amer. J. Physiol., 218: 956 (1970).

14. This research was supported by Grant HD08639 from the NIH.

15. Requests for reprints should be addressed to: Herbert S. Harned, Jr., M.D. Department of Pediatrics, University of North Carolina School of Medicine, Chapel Hill, NC 27514 (USA).

16. Received for publication August 10, 1977

17. Accepted for publication January 10, 1978. 